J. Lake Sci. (湖泊科学), 2013, 25(3):317-323

http: //www. jlakes.org. E-mail: jlakes@niglas.ac.cn

(C) 2013 by Journal of Lake Sciences

\title{
河道型水库水动力特征与气候条件的响应关系”
}

李一平 ${ }^{1,2}$, 滑 否 ${ }^{2 * *}$, 王沛芳 ${ }^{1,2}$, 王 超 ${ }^{1,2}$, 谈永锋 ${ }^{3}$

( 1 : 河海大学浅水湖泊综合治理与资源开发教育部重点实验室,南京 210098)

( 2 : 河海大学环境学院,南京 210098$)$

(3:南京市水利规划设计院有限责任公司,南京 210006)

摘 要: 气候条件 (降雨、气温) 的变化对流域内水资源、河道、湖库的径流影响较大. 河道型水库由于具有河道和湖泊的 双重特点, 受气候条件的影响则更为显著. 本文以广东省梅州的河道型水库一一长潭水库为例, 耦合流域分布式水文模 型 SWAT 与环境流体动力学模型 EFDC, 研究了河道型水库水动力特征 ( 以水龄表征) 与气候条件的响应关系. 根据梅县 气象站 1953-2010 年共 58 年的年均降雨量资料的频率分析, 选取降雨量保证率分别为 20\% (丰水年)、50\% (平水年) 和 $90 \%$ (枯水年) 年份的气候条件作为 3 种气候方案, 对应的典型年分别为 1992、1988 和 2004 年, 并将各典型年的日均降雨 量和气温作为 SWAT 水文模型的输人条件, 模拟了进人长潭水库各主要支流的日均变化过程. 并将该流量过程作为长潭 水库库区水动力模型的人流边界, 模拟了各种降雨典型年情景下长潭水库的水动力变化过程. 结果表明, 长潭水库库区 水龄沿程逐渐增大, 呈指数增长的趋势, 且受气候条件的影响很大. 与丰水年相比, 平水年、枯水年年降雨量分别减少了 $14 \%$ 和 $49 \%$, 人库径流分别减少了 $23 \%$ 和 $62 \%$, 水库出库坝址附近水龄分别增大了 $66 \%$ 和 $247 \%$, 支流区域水龄增幅可 达 $81 \%$ 和 $290 \%$ 左右, 可见水库水动力特征受气候条件影响很大, 而支流区域受气候条件影响更显著. 不同气候条件下, 河道型水库分别呈现出河道和深水湖泊的双重特性. 丰水年时, 坝址附近垂向上水体交换频繁, 水龄均匀, 呈现出河道的 特性; 平水年与枯水年时,坝址附近水体垂向交换较弱,逐渐呈现出深水湖泊的垂向分层特性. 另外,流域分布式水文模 型 SWAT 与环境流体动力学模型 EFDC 的联用, 为弥补历史长系列高频监测资料的缺失, 提高湖库水动力模型模拟的精 度提供了有效的方法.

关键词: 环境水力学;水龄;EFDC 模型;SWAT 模型;河道型水库;长潭水库

\section{Responses of hydrodynamical characteristics to climate conditions in a channel-type res- ervoir}

LI Yiping ${ }^{1,2}$, HUA Lei ${ }^{2}$, WANG Peifang ${ }^{1,2}$, WANG Chao ${ }^{1,2} \&$ TAN Yongfeng ${ }^{3}$

(1: Key Laboratory of Integrated Regulation and Resource Development on Shallow Lakes of Ministry of Education, Hohai University, Nanjing 210098, P. R. China)

(2: College of Environment, Hohai University, Nanjing 210098, P. R. China)

(3: Nanjing Water Planning and Designing Institute Co. Ltd. , Nanjing 210006, P. R. China)

Abstract: Changes of rainfall and temperature caused by climate changes have a great impact on water resource and runoff in watershed. Channel-type reservoir, due to its characteristics of river and lake, is affected intricately by climate. As a case study of Changtan Reservoir in Meizhou City, Guangdong Province, coupled watershed hydrological model SWAT and Environmental Fluid Dynamic Code (EFDC) have been used to study the responses of hydrodynamics (characterization by water age) to climate condition in the channel-type reservoir. According to frequency analysis of 58 years rainfall data from 1952 to 2010 in Meizhou City, selected rainfall guarantee rates are 20\% (wet year), 50\% (average year) and 90\% (dry year) as three climate schemes. Tributaries of Changtan Reservoir were simulated with the rainfall and temperature in the typical years as input conditions for SWAT mod-

* 水利部公益性行业科研专项经费项目(201101020)、国家自然科学基金项目 (51009049)、江苏省高校 “青蓝工程” 项目和河海大学创新人才计划项目联合资助. 2012-08-10 收稿;2012-10-15 收修改稿. 李一平,男,1978 年生, 博士,副教授;E-mail:liyiping@ hhu. edu.cn.

** 通信作者;E-mail:hualei@ hhu. edu.cn. 
el, and hydrodynamics process was simulated with the inflow of the tributaries as boundary conditions. The results showed that, water age increased exponentially along Changtan Reservoir, and was greatly affected by climate conditions. Compared to wet year, in average year and dry year, annual rainfall reduced $14 \%$ and $49 \%$, and inflow reduced $23 \%$ and $62 \%$, and water age increased $66 \%$ and $247 \%$ near the outlet dam, and up to $81 \%$ and $290 \%$ in tributaries, respectively. So, climate conditions had a great effect on the reservoir's hydrodynamics, especially in the vicinity of tributaries. Changtan Reservoir exhibited the characteristics of river and lake under different climatic conditions. Near the dam, it exhibited the characteristics of river in wet year, and the characteristics of lake in average and dry year gradually. Additionally, coupling of watershed hydrological model SWAT and EFDC, it is an effective method for making up the needed long series of high frequency measured data and improving the accuracy of hydrodynamic model simulation in lake and reservoir.

Keywords: Hydrodynamics; water age; EFDC; SWAT; channel-type reservoir; Changtan Reservior

河道型水库具有河流和水库的双重特性 ${ }^{[1]}$, 与一般水库不同, 河道型水库水深与水面宽都远小于库长; 枯 水期上游来水较少, 水库处于高水位运行, 呈现水库和湖泊的特性; 洪水期因防洪需要, 水库低水位运行, 来水 流量基本等于泄水量, 呈现河道的特性. 因此河道型水库水动力及污染物传输特征受边界条件影响很大, 而降 雨、温度等气候元素对河道型水库边界影响很大. 因此,气候条件对河道型水库水动力特征有很大影响. 胡 彩虹等 ${ }^{[2]}$ 定量分析了气候变化对汾河水库人库径流的贡献. 夏军等 ${ }^{[3]}$ 研究了气候变化对密云水库水资源的 影响, 唐芳芳 ${ }^{[4]}$ 、沈华东 ${ }^{[5]}$ 等用 SWAT (Soil and Water Assessment Tool) 模型 ${ }^{[6]}$ 模拟了不同流域与气候条件的 响应关系. 这些研究主要考虑气候对水库水资源量的影响, 但是很少进一步分析气候对水库水动力特征的 影响. 特别是对于很多研究区域, 缺乏长系列的历史监测资料, 增加了构建水库水环境数学模型的难度. 如 何找到一种有效的方法解决无资料地区的水环境预测问题一直是研究的热点和难点.

另外,湖库富营养化是我国目前水环境面临的重大问题. 湖库的污染负荷及停留时间是湖库富营养化 的重要影响因素, 受水动力过程影响很大. 故寻求合适的参数来描述湖库水体的交换强度或交换过程是了 解富营养化发生机理的基础和前提. 湖库水动力的交换过程一般采用换水周期、交换周期或水力停留时间 等来反映,但往往是采取一个值来反映湖库水体交换的平均周期, 不能反映水体交换强度在空间上的变异 性,然而湖库的水动力过程在空间上往往具有分异性. 为了解决这一问题, 李一平等 ${ }^{[7]}$ 和郝文彬等 ${ }^{[8]}$ 等将水 龄的概念引人到反映我国太湖水体交换特征的空间分异性研究中, 取得了较好的效果. 水龄的概念最早由 Zimmerma $^{[9]}$ 于 1976 年提出, 定义为可溶性物质从人口传输到指定位置所需要的时间(往往人口处的水龄设 为零). 水龄越大, 说明水体运动越慢, 水体被交换程度越弱. Delhez 等 ${ }^{[10]} 1999$ 年用平流扩散方程提出了水 龄的理论并将其应用到数值模型中. Shen 等 ${ }^{[11]}$ 用 CH3D 模型模拟了美国 Chesapeake 湾的水龄分布, Shen 等 ${ }^{[12]}$ 用 FVCOM 模型模拟了辽宁大伙房水库的水龄分布,效果很好.

本文以广东省梅州市长潭水库为例, 利用流域分布式水文模型 SWAT 与环境流体动力学模型 EFDC (Environmental Fluid Dynamic Code $)^{[13]}$,构建了长潭水库流域水文一库区水动力学模型, 以水龄表征水动力 特征,研究了不同典型气候条件对河道型水库水动力特征 ( 以水龄表征) 的影响.

\section{1 研究区域}

长潭水库 $\left(24^{\circ} 42^{\prime} 2^{\prime \prime} \sim 24^{\circ} 50^{\prime} 15^{\prime \prime} \mathrm{N}, 116^{\circ} 4^{\prime} 8^{\prime \prime} \sim 116^{\circ} 8^{\prime} 1^{\prime \prime} \mathrm{E}\right)$ 位于广东省梅州市蕉岭县蕉城镇西北约 $6 \mathrm{~km}$ 的石窟河长潭峡谷中, 是以发电、供水、防洪为主要功能的大 (二) 型水库. 长潭水库上游电站较多, 调度资料 短缺, 本次研究仅考虑长兴电站坝址至长潭水库坝址之间库区的集水区域. 该区域周边多为山区林地, 人为 开发利用程度较低,集水区域面积为 $259.3 \mathrm{~km}^{2}$. 长潭水库长兴电站坝址至长潭水库坝址之间全长约 $22 \mathrm{~km}$, 宽 $100 \sim 350 \mathrm{~m}$, 平均水深 $30 \mathrm{~m}$, 库容 $1.4 \times 10^{8} \mathrm{~m}^{3}$, 水面面积 $4.3 \mathrm{~km}^{2}$, 属于典型的河道型水库. 水库位置及形 状见图 1. 水库来水主要由上游长兴电站下泄流量和长潭水库流域降雨汇流组成, 其中长兴电站上游来水占 水库来水量的 $85 \%$ 以上. 近年来, 长潭水库水体污染负荷过大, 导致局部地区富营养化严重, 对下游用户用 水造成了一定的威胁.

\section{2 流域水文模型和库区水动力模型的构建}

本文利用 SWAT 分布式水文模型和 EFDC 模型来构建长潭水库流域水文模型和库区水动力模型. 


\section{1 长潭水库流域水文模型的构建}

根据长潭水库流域 1:10000 地形图 ( DEM)、1:10000 土地利用类型图、1:1000000 土壤类型图及梅县气象 站的降雨、气温数据构建长潭水库流域水文模型. DEM 图经过填洼处理后,利用辨识分水岭方法将长潭水库 流域划分为 25 个子流域,并利用 DEM 生成的主要人库河道及现场勘查结果将长潭水库流域主要人库河道 概化为 7 条 (图 1 ).
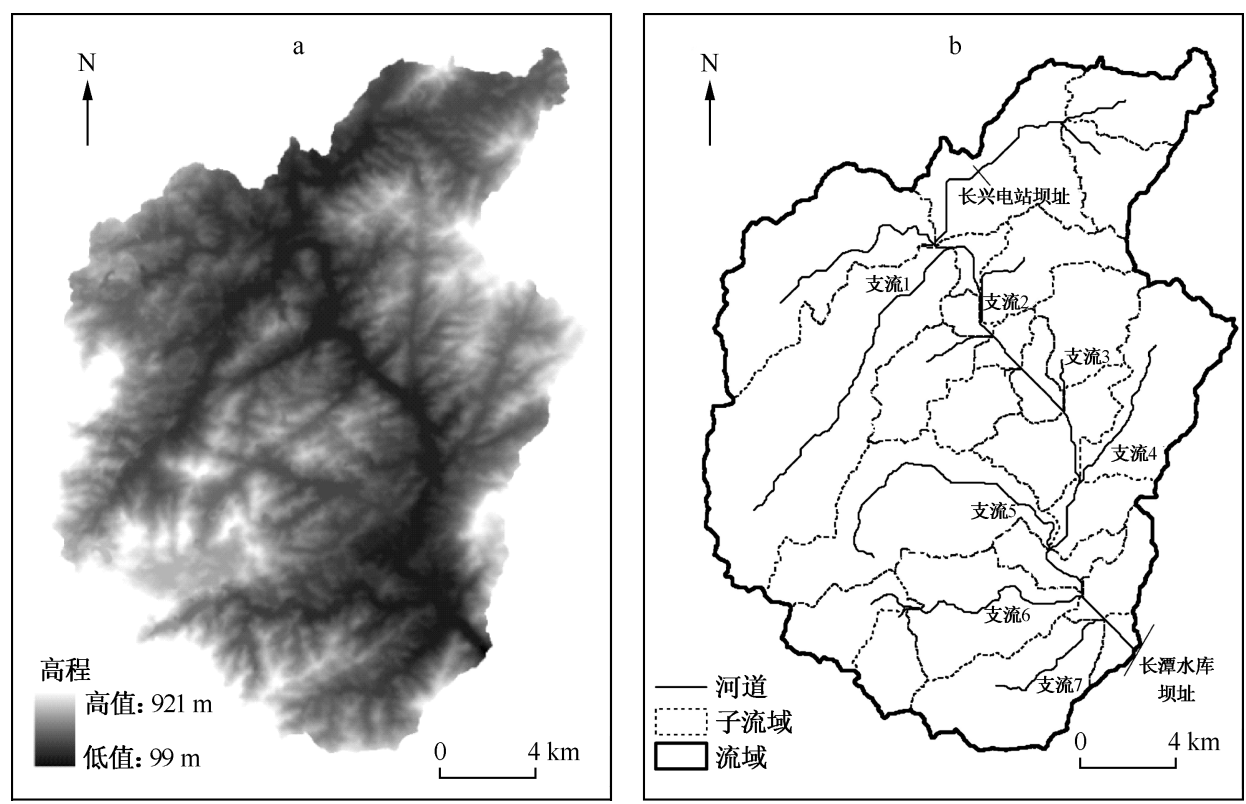

图 1 长潭水库 DEM 图(a)、子流域及概化河道 $(\mathrm{b})$

Fig. 1 Changtan Reservoir generated by $\operatorname{DEM}(\mathrm{a})$ and subbasins and tributaries(b)

\section{2 长潭水库库区水动力模型的构建}

长潭水库库区模型上边界始于长兴电站, 下边界为长潭水库大坝坝址, 共 $22 \mathrm{~km}$. 模型范围内包含库区 及 7 条主要人库支流 (由流域水文模型自动判别得出并经过现场确认), 其边界坐标在 Google Earth 中提取 得出. 模型范围内在平面上共划分 11214 个正方形网格, 网格距为 $20 \mathrm{~m}$. 库区模型范围的底高程由 DEM 数 据和现场监测数据经过内插获取. 为了较好地模拟水库底部地形, 垂直方向采用 $\sigma$ 坐标, 平均分为 10 层, 用 库底和表层水体厚度来定义垂向网格的高度. 根据流体静力学连续性和避免产生 $\sigma$ 坐标带来的压力梯度错 误,应使库底坡度小于 $0.33^{[7]}$.

采用水库代表气候条件下长兴电站及长潭水库坝址调度流量做为长潭水库库区水动力模型上、下游边 界,将流域模型概化的 7 条人库河道作为水库支流汇人,其流量资料由流域模型计算得出.

为了定量分析气候条件对长潭水库水动力特征的影响, 选取库区内不同代表点对水龄进行分析. 长潭 水库概化河道位置及选取代表点见图 2, 其中点 $A 、 B 、 D 、 E 、 F 、 H$ 为水库计算区域上游至下游主河道的中心 点, 点 $\mathrm{C}$ 位于支流 1 汇人水库处, 点 $\mathrm{G}$ 位于支流 6 中心. 同时为便于分析, 将长潭水库分为 3 段: 长兴电站坝 址至支流 2 人库断面之间的库区为水库上游 (约 $8 \mathrm{~km}$ ); 支流 2 至支流 5 汇人主库区处之间的库区为水库中 游 (约 $10 \mathrm{~km}$ ) ; 支流 5 汇人主库区处至长潭水库坝址之间库区为水库下游 (约 $4 \mathrm{~km}$ ).

EFDC 模型对水动力的模拟已经十分成熟,故模型大部分参数都未作改变.

\section{3 模型验证}

利用构建的长潭水库流域模型和库区水动力模型, 选取库区附近的梅县气象站 2010 年 1-5 月份 (共 $151 \mathrm{~d})$ 的逐日降雨和气温资料驱动水文模型, 长潭水库库区上、下边界采用长兴电站和长潭水库电站逐日的 调度资料, 人库支流采用水文模型的模拟数据. 计算得出长潭水库的水位和流量变化过程, 对模型选定的参 


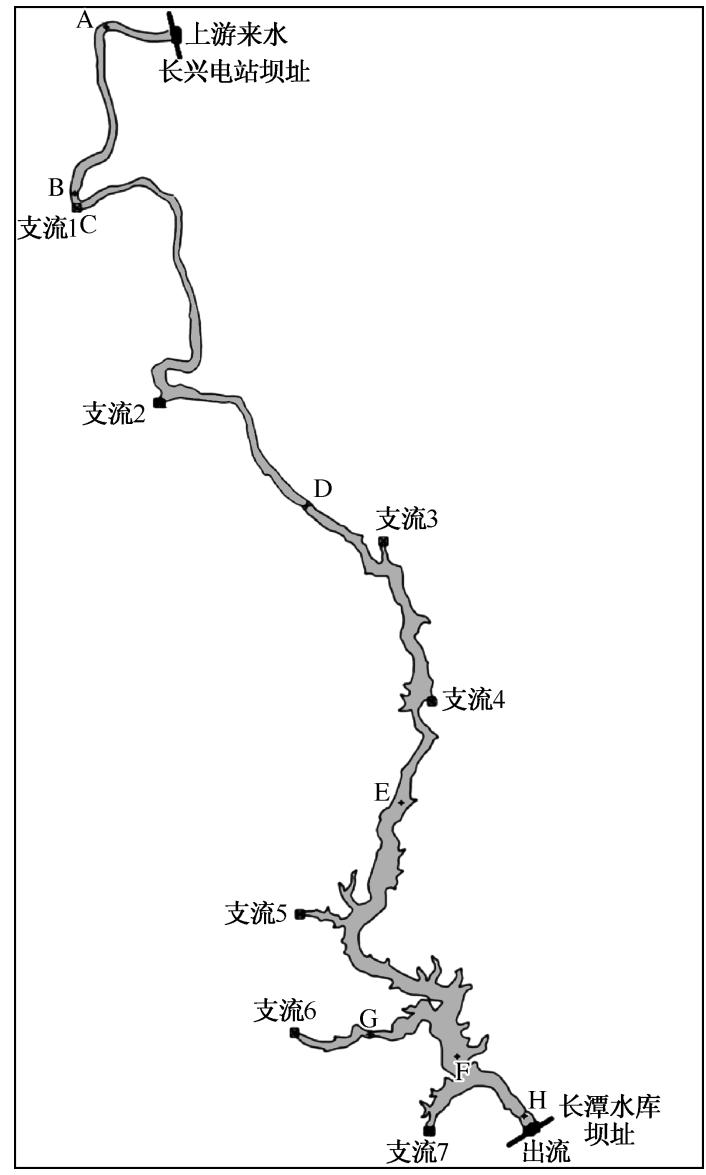

图 2 长潭水库概化河道及代表点位置

Fig. 2 Location of rivers and points for analysis in Changtan Reservoir

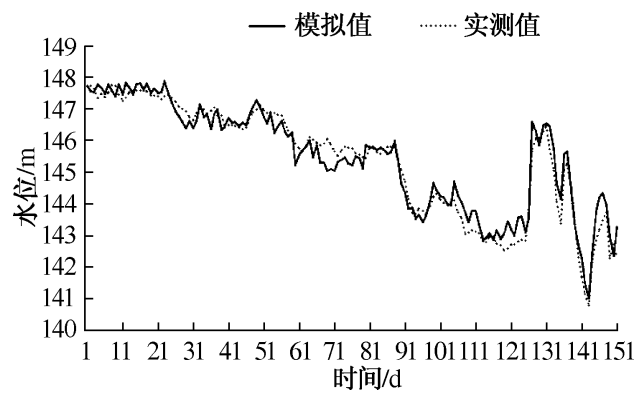

图 3 长潭水库流域一水动力模型验证结果

Fig. 3 Validation result of watershed-hydrodynamic model in Changtan Reservoir
数进行验证. 计算结果表明, 长潭水库坝址的计算 水位和流量与实测值均拟合得较好, 相对误差在 $5 \%$ 以内 (图 3 ), 说明该模型能很好地反映水库的 水动力过程, 参数选取合理.

\section{4 模拟方案}

根据梅县气象站 1953-2010 年共 $58 \mathrm{a}$ 的年均 降雨量资料的频率分析, 选取降雨量保证率分别为 $20 \%$ (丰水年)、50\% (平水年)、90\%（枯水年)年份 的气候条件作为 3 种气候方案, 对应的典型年分别 为 $1992 、 1988$ 和 2004 年. 并将典型年 1992 年(方案 1)、1988 年(方案 2 ) 和 2004 年 (方案 3 ) 的逐日降 雨量和逐日气温作为 SWAT 水文模型的 3 种输人 条件, 模拟了进人长潭水库各主要支流和上游人流 流量的日均变化过程. 并将该流量过程作为长潭水 库库区水动力模型的人流边界, 模拟了 3 种方案下 长潭水库的水动力变化过程. 1992、1988 和 2004 年 年降雨量和年平均气温分别为 $2048 、 1771 、 1035 \mathrm{~mm}$ 和 20.9、21.0、21. $6^{\circ} \mathrm{C}, 3$ 种方案降雨量依次减少, 温度依次升高,具有一定的代表性.

\section{3 结果与讨论}

长潭水库为典型的河道型水库, 因水库狭长 且不同气候条件下水深变化较大, 水龄空间分异 性较大, 故本文分别从库区水龄的平面分布和沿 水深方向的垂向分布进行分析和讨论. 本文讨论 水龄平面分布时将库区各点垂向上的水龄值进行 算术平均,讨论垂向分布时是提取从长兴电站坝 址至长潭水库坝址之间的主库区中心线上的水 龄值.

\section{1 不同气候条件下长潭水库水龄平面分布特征}

根据 3 种方案气候条件下长潭水库水龄平面 分布 (图 4) 可知,长潭水库计算区域内水龄值沿程 逐渐增大. 方案 1 (丰水年) 长潭水库上游、中游、下 游水龄值分别在 $0 \sim 2 、 2 \sim 10 、 10 \sim 20 \mathrm{~d}$ 之间, 以上 游、中游、下游代表点 $\mathrm{B} 、 \mathrm{E} 、 \mathrm{~F}$ 为例, 这 3 点的水龄 值分别为 $0.9 、 7.1 、 16.5 \mathrm{~d}$; 方案 2 (平水年) 长潭 水库上游、中游、下游水龄值分别在 $0 \sim 5 、 5 \sim 18$ 、 $18 \sim 25 \mathrm{~d}$ 之间, $\mathrm{B} 、 \mathrm{E} 、 \mathrm{~F}$ 点的水龄值分别为 1.9 、 $13.1 、 27.2 \mathrm{~d}$;方案 3 (枯水年) 长潭水库上游、中游、 下游水龄值分别在 $0 \sim 10 、 10 \sim 40 、 40 \sim 70 \mathrm{~d}$ 之间, $B 、 E 、 F$ 点的水龄值分别为 $4.1 、 29.1 、 58.9 \mathrm{~d}$. 通过 3 种气候条件下水库计算区域河道中心沿程水龄的拟合关系 (图 5 ) 可知, 库区河道中心水龄沿程呈指数增 长的趋势. 由于水龄反映水体被上游来水交换所需的时间,因此计算区域内上游至下游水库的水龄逐渐 增大,库区水体被上游来水交换所需的时间逐渐变长. 


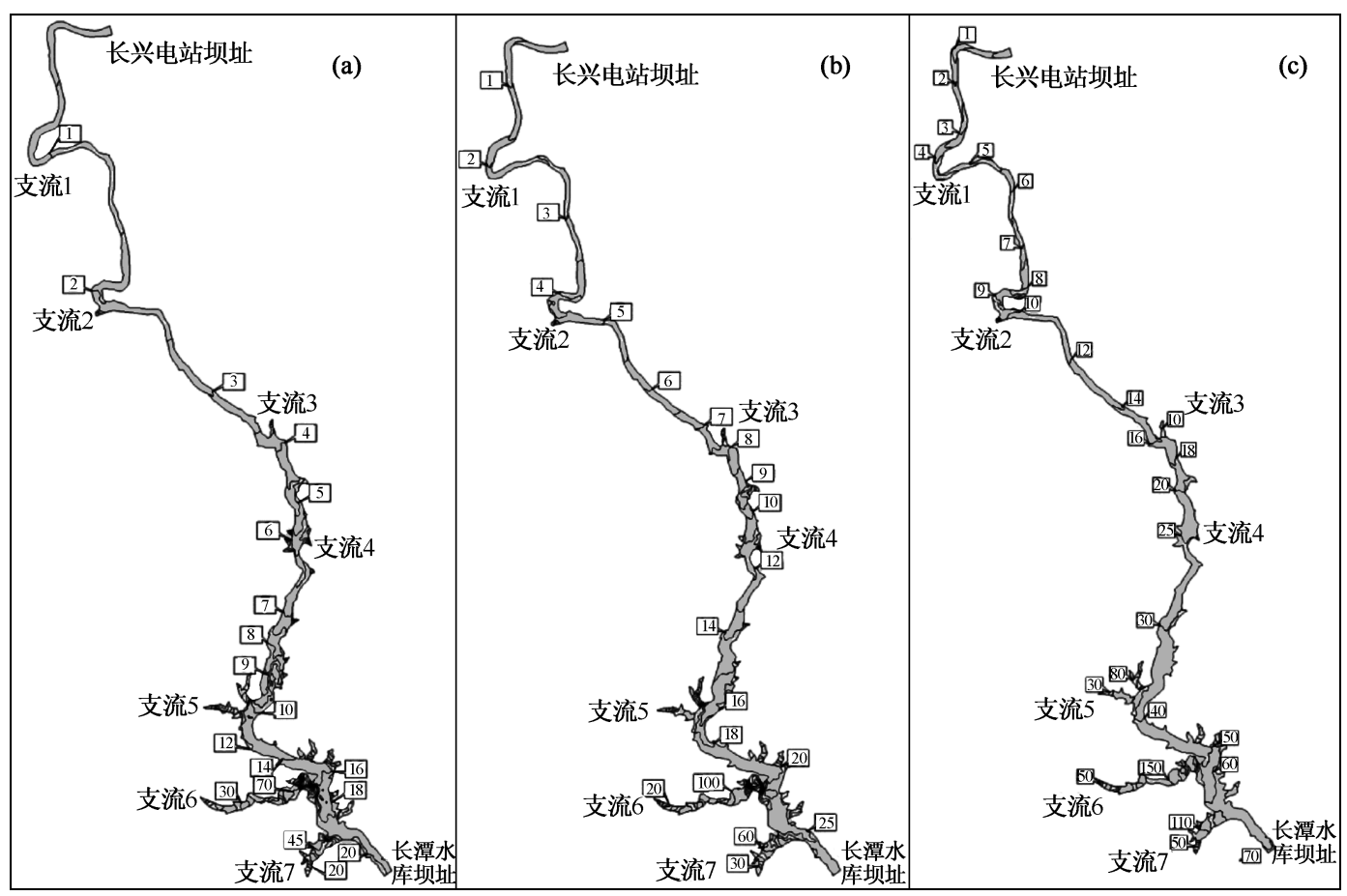

图 4 长潭水库水龄分布: (a) 方案 1 ; (b) 方案 2 ; (c) 方案 3

Fig. 4 Water age distribution in Changtan Reservoir:(a) case 1; (b) case 2; (c) case 3

在支流流域面积较大的区域, 支流附近库区水龄较小, 支流来水对该区域水动力交换改善效果显著, 以 支流 2 附近点 $\mathrm{C}$ 为例, 与支流 2 上游附近点 $\mathrm{B}$ 相比, 方案 1 、方案 2 、方案 3 点 $\mathrm{C}$ 处水龄值比点 $\mathrm{B}$ 处分别减少 $0.2 、 0.3$ 和 $0.6 \mathrm{~d}$; 而在支流较长且汇流面积较小的河段, 水龄普遍大于主库区水龄值, 以支流 6 中点 $\mathrm{G}$ 和长 潭水库坝址附近点 $\mathrm{H}$ 为例, 3 种气候方案下点 $\mathrm{G}$ 水龄值比点 $\mathrm{H}$ 分别大 $20.2 、 39.1$ 和 $87.2 \mathrm{~d}$. 可见支流的水 龄值受汇水面积及河段长度的影响较大,在汇水面积较小而河段较长的区域由于径流量较小,水体交换较 差,容易发生水体富营养化.

3 种气候条件下年降雨量及人库径流量变化很大,方案 2 (平水年) 和方案 3 (枯水年) 较方案 1 (丰水年) 年降雨量分别减少了 $14 \%$ 和 $49 \%$, 因气候条件引起的人库径流量分别减少了 $23 \%$ 和 $62 \%$. 而长潭水库计算 区域内水龄值变化亦很大. 通过不同方案长潭水库河道中心沿程水龄值 (图 5) 可知, 越往下游, 长潭水库沿 程水龄差值越大. 长潭水库上游以点 $\mathrm{B}$ 为例, 方 案 2 和方案 3 较方案 1 水龄值分别增大了 1.0 和 $2.2 \mathrm{~d}$, 即分别增加了 $111 \%$ 和 $244 \%$; 长潭水 库中游以点 $\mathrm{E}$ 为例, 方案 2 和方案 3 较方案 1 水 龄值分别增大了 6.0 和 $22.0 \mathrm{~d}$, 即分别增加了 $85 \%$ 和 $310 \%$; 长潭水库下游以点 $\mathrm{H}$ 为例, 方案 2 和方案 3 较方案 1 水龄值分别增大了 13.1 和 $48.0 \mathrm{~d}$, 即分别增加了 $66 \%$ 和 $247 \%$; 长潭水库 支流以点 $\mathrm{G}$ 为例, 方案 2 和方案 3 较方案 1 水龄 值分别增大了 32.0 和 $115.0 \mathrm{~d}$, 即分别增加了 $81 \%$ 和 $290 \%$. 由此可知气候条件对长潭水库水 动力条件特征影响很大, 支流受气候变化影响 更大。

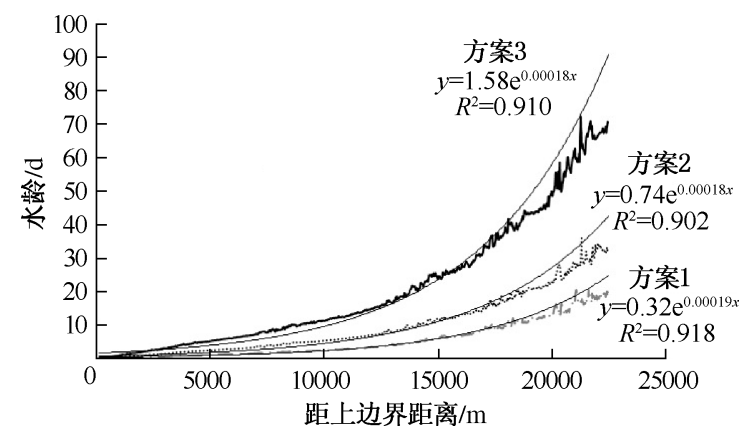

图 5 不同方案长潭水库河道中心沿程水龄值

Fig. 5 Water age distribution under different cases 


\section{2 不同气候条件下长潭水库水龄垂向分布特征}

由长潭水库库区河道中心水龄沿程垂向分布 (图 6) 可知, 长潭水库库区水龄从计算区域上游至下游逐 渐增大, 垂向上水龄变化不大. 3 种气候条件下, 方案 1 (丰水年)上游 (距上边界 $0 \sim 8 \mathrm{~km}$ 范围)、中游 (距上 边界 $8 \sim 18 \mathrm{~km}$ 范围)、下游 (距上边界 $18 \sim 22 \mathrm{~km}$ 范围) 水龄分别在 $0 \sim 2 、 2 \sim 10 、 10 \sim 22 \mathrm{~d}$ 之间; 上游及中游 水龄垂向变化都小于 $1 \mathrm{~d}$,下游水龄垂向变化在 $1 \sim 4 \mathrm{~d}$ 之间. 方案 2 (平水年) 上游、中游、下游水龄分别在 $0 \sim 4 、 4 \sim 18 、 18 \sim 36 \mathrm{~d}$ 之间; 上游水龄垂向变化都小于 $1 \mathrm{~d}$, 中游水龄垂向变化都小于 $2 \mathrm{~d}$,下游水龄垂向变化 在 $2 \sim 6 \mathrm{~d}$ 之间. 方案 3(枯水年) 上游、中游、下游水龄分别在 $0 \sim 9 、 9 \sim 40 、 40 \sim 80 \mathrm{~d}$ 之间; 上游水龄垂向变化 都小于 $1 \mathrm{~d}$, 中游水龄垂向变化都小于 $5 \mathrm{~d}$,下游水龄垂向变化在 $5 \sim 10 \mathrm{~d}$ 之间. 可知长潭水库从上游至下游 垂向水动力交换逐渐变弱.

长潭水库坝址附近,方案 2 和方案 3 水龄垂向变化比方案 1 分别增大了 2 和 $4 \mathrm{~d}$,水龄垂向分层逐渐明 显. 不同气候条件下, 当人库流量较大时 (丰水年), 水库低水位运行, 水体流速较大, 库区水体交换频繁, 水 龄分布均匀,水库呈现出河道的特性. 随着人库流量的减小 (平水年, 枯水年), 水库运行水位抬高, 水体流速 变小,主库区坝址附近垂向上水体交换较弱,水龄出现明显的分层,水库逐渐呈现出湖泊的特性,容易造成

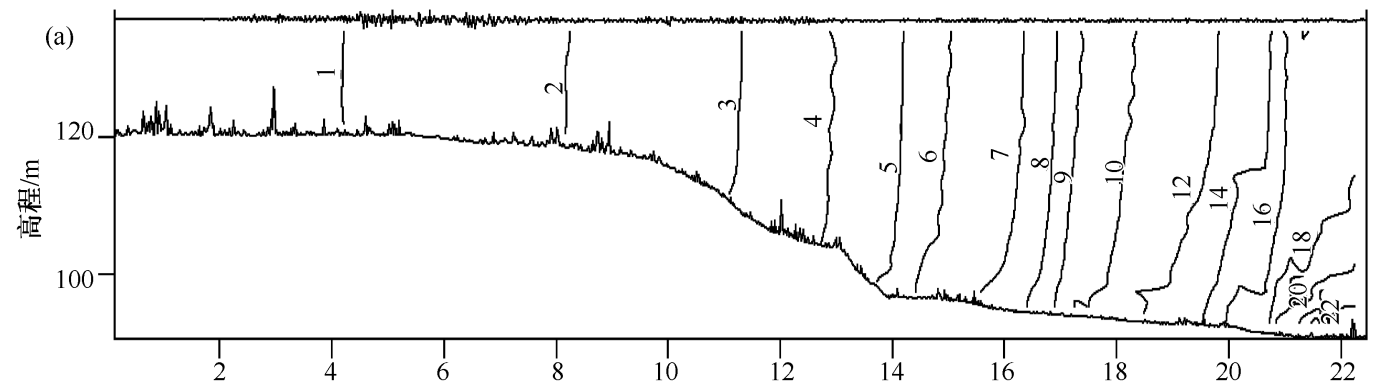

距上边界距离 $/ \mathrm{km}$

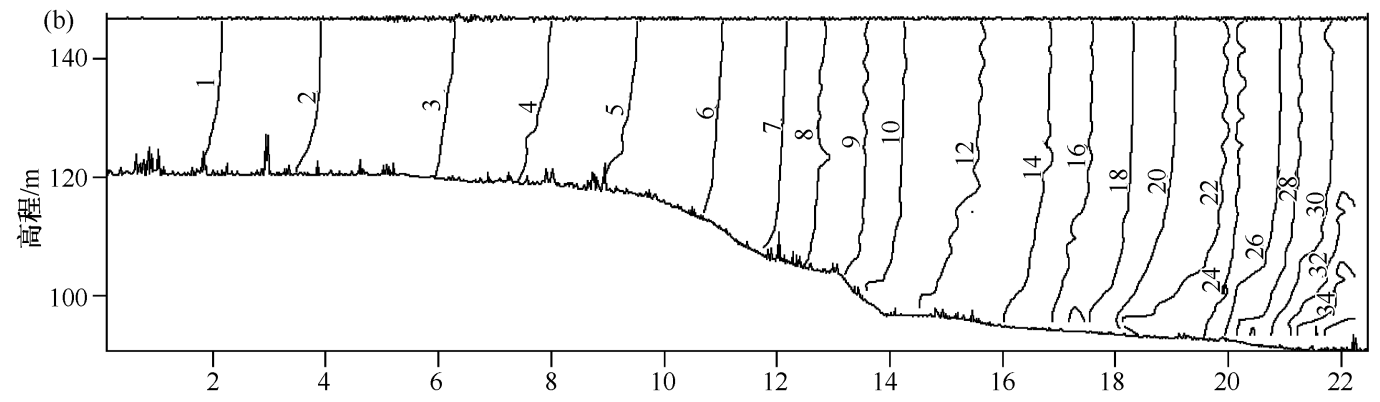

距上边界距离 $/ \mathrm{km}$

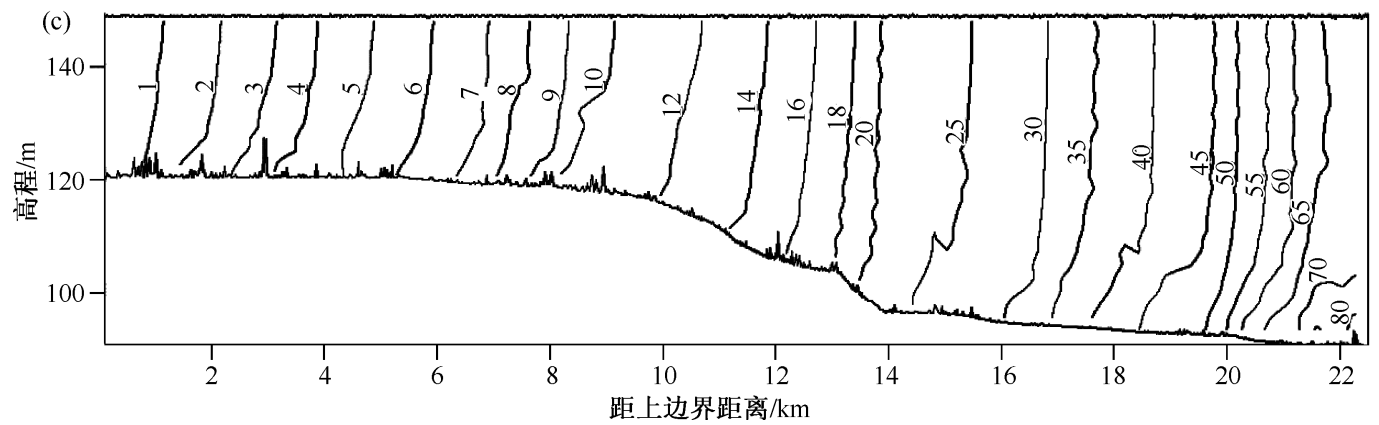

图 6 不同方案长潭水库计算区域沿程水龄垂向分布: (a) 方案 1 ; (b) 方案 2 ; (c) 方案 3

Fig. 6 Vertical water age distribution in Changtan Reservoir: (a) case 1; (b) case 2; (c) case 3 
污染物富集, 水质变差, 出现富营养化; 而主库区上游河道水龄垂向上变化很小, 水库底部水体交换较好, 依 然呈现出河道的特性. 水库的水动力特性受气候条件影响很大.

\section{4 结论}

本文以长潭水库为例, 利用 SWAT 和 EFDC 模型构建了长潭水库流域水文一库区水动力学模型, 结果表 明,构建模型能很好地反映长潭水库水动力特征. 利用该模型模拟 3 种代表性气候条件(丰水年、平水年、枯 水年)下长潭水库水动力学特征得出以下结论:

1) 水龄主要反映水体被上游来水交换所需的时间,能够很好地反映水体水动力特征. 对于一般水库,水 龄沿程逐渐增大, 即越往下游, 上游水体到达的时间越长, 主库区上游水体交换比下游水体交换较好. 对于 河道型水库, 主库区水龄沿程逐渐增大, 且呈指数增长.

2) 支流的水龄值受汇水面积影响较大. 对于汇水面积大的支流, 支流附近水龄值较小, 支流的汇人有利 于改善附近的水动力交换效果; 而对于汇水面积较小的支流, 水龄值普遍很大, 水动力交换弱, 是潜在的富 营养化区域.

3) 不同气候条件下,随着降雨减少、温度升高, 流域内径流量减少, 人库径流量较少, 水库水龄明显变 大,水体交换变弱. 对于长潭水库, 与丰水年相比,平水年和枯水年年降雨量分别减少了 $14 \%$ 和 $49 \%$, 人库径 流量分别减少了 $23 \%$ 和 $62 \%$, 相应的水库下游坝址附近水龄分别增大 $66 \%$ 和 $247 \%$, 支流区域水龄增幅可 达 $81 \%$ 和 $290 \%$ 左右. 水库水动力特征对气候条件敏感, 支流区域受气候条件影响更显著.

4 ) 不同气候条件下,河道型水库分别呈现出河道和湖泊的双重特性. 丰水年时,主库区垂向上水体交换 频繁, 水龄均匀, 呈现出河道的特性; 平水年与枯水年时, 坝址附近水体垂向交换较弱, 水龄出现明显分层, 逐渐呈现出湖泊的垂向分层特性,容易发生富营养化.

\section{5 参考文献}

[ 1 ] 董克斌. 河道型水库中流速对水华影响研究——藻类生长研究 [ 学位论文]. 重庆: 重庆大学, 2010.

[2] 胡彩虹,管新建, 吴 泽等. 水土保持措施和气候变化对汾河水库人库径流贡献定量分析. 水土保持学报,2011,25 (5) $: 12-16$.

[3] 夏 军,李 璐, 严茂超等. 气候变化对密云水库水资源的影响及其适应性管理对策. 气候变化研究进展, 2008,4 (6) :319-323.

[ 4 ] 唐芳芳,徐宗学,左德鹏. 黄河上游流域气候变化对径流的影响. 资源科学, 2012,34(6): 1079-1088.

[5] 沈华东, 于 革. 青藏高原兹格塘错流域 50 年来湖泊水量对气候变化响应的模拟研究. 地球科学与环境学报, $2011, \mathbf{3 3}$ (3) :282-287.

[ 6 ] Neitsch SL, Arnold JG, Kiniry RJ et al. Soil and water assessment tool theoretical documentation, 2000. http: //www. brc. tamus. edu/swat. 2004.

[ 7 ] Li YP, Achary K, Yu ZB. Modeling impacts of Yangtze River water transfer on water ages in Lake Taihu, China. Ecological Engineering, 2011, 37 : 325-334.

[8] 郝文斌, 唐春燕, 滑 否等. 引江济太调水工程对太湖水动力的调控效果. 河海大学学报: 自然科学版, 2012,40 (2) : 129-133.

[ 9 ] Zimmerman J. Mixing and flushing of tidal embayments in the Western Dutch Wadden Sea, Part I: distribution of salinity and calculation of mixing time scales. Netherlands Journal of Sea Research, 1976, 10:149-191.

[10 ] Delhez E, Campin J, Hirst A et al. Toward a general theory of the age in ocean modeling. Ocean Modeling, 1999, (1) :17-27.

[11] Shen J, Wang H. Determining the age of water and long-term transport timescale of the Chesapeake Bay. Estuarine, Coastal and Shelf Science, 2007, 74: 585-598.

[12] Shen YM, Wang JH, Zheng BH et al. Modeling study of residence time and water age in Dahuofang Reservoir in China. Science China (Physics, Mechanics \& Astronomy), 2011,54(1) : 127-142.

[13 ] Hamrick J. A three-dimensional environmental fluid dynamics computer code: Theoretical and computational aspects. The College of William and Mary, Virginia Institute of Marine Science. Special Report 317, 1992. 